\title{
Variability of Microbial Communities in Two Long-term Ice-covered Freshwater Lakes in the Subarctic Region of Yakutia, Russia
}

\section{Yulia Robertovna Zakharova}

Limnological Institute, Siberian Branch of Russian Academy of Sciences, 3, Ulan Batorskaya Street, Irkutsk 664033, Russia

Maria Victorovna Bashenkhaeva ( $\square$ maria.bashenkhaeva@gmail.com )

Limnological Institute SB RAS https://orcid.org/0000-0002-2551-5153

Yuri Pavlovich Galachyants

Limnological Institute, Siberian Branch of Russian Academy of Sciences, 3, Ulan Batorskaya Street, Irkutsk 664033, Russia

\section{Darya Petrovna Petrova}

Limnological Institute, Siberian Branch of Russian Academy of Sciences, 3, Ulan Batorskaya Street, Irkutsk 664033, Russia Irina Victorovna Tomberg

Limnological Institute, Siberian Branch of Russian Academy of Sciences, 3, Ulan Batorskaya Street, Irkutsk 664033, Russia Artyom Mikhailovich Marchenkov

Limnological Institute, Siberian Branch of Russian Academy of Sciences, 3, Ulan Batorskaya Street, Irkutsk 664033, Russia

Liubov Innokentyevna Kopyrina

Limnological Institute, Siberian Branch of Russian Academy of Sciences, 3, Ulan Batorskaya Street, Irkutsk 664033, Russia

Yelena Valentinovna Likhoshway

Limnological Institute, Siberian Branch of Russian Academy of Sciences, 3, Ulan Batorskaya Street, Irkutsk 664033, Russia

\section{Research Article}

Keywords: Subarctic freshwater lakes, ice-covered period, microbial communities, cultivable bacteria, 16S rRNA sequences

Posted Date: May 27th, 2021

DOI: https://doi.org/10.21203/rs.3.rs-529765/v1

License: (a) This work is licensed under a Creative Commons Attribution 4.0 International License. Read Full License 


\section{Abstract}

Although under-ice microbial communities are subject to a cold environment, low concentrations of nutrients, and a lack of light, they nevertheless take an active part in biogeochemical cycles. However, we still lack an understanding of how high their diversity is and how these communities are distributed during the long-term ice-cover period. Here we assessed for the first time the composition and distribution of microbial communities during the ice-cover period in two subarctic lakes (Labynkyr and Vorota) located in the area of the lowest temperature in the Northern Hemisphere. The diversity distribution and abundance of main bacterial taxa, and the composition of microalgae, varied by time and habitat. The 16S rRNA gene sequencing method revealed, in general, a high diversity of bacterial communities where Proteobacteria ( 59\%) and Actinobacteria ( 11\%) prevailed. There were significant differences between the communities of the lakes: Chthoniobacteraceae, Moraxellaceae, and Pirellulaceae were abundant in Lake Labynkyr, while Cyanobacteria, Oligoflexales, Ilumatobacteraceae, and Methylacidiphilaceae were more abundant in Lake Vorota. The most abundant families were evenly distributed in April, May and June their contribution was different in different habitats. Moraxellaceae, Ilumatobacteraceae dominated in April in the water column, while Sphingomonadaceae dominated both in water column and on the ice bottom. In May, the number of Comamonadaceae increased and reached the maximum in June, while Cyanobacteria, Oxalobacteraceae and Pirellulaceae followed. We found a correlation of the structure of bacterial communities with snow thickness, $\mathrm{pH}$, total nitrogen concentration, and conductivity. We isolated psychrophilic heterotrophic bacteria both from dominating and minor taxa of the communities studied. This allowed for specifying their ecological function in the under-ice communities. These findings will advance our knowledge of the under-ice microbial life.

\section{Introduction}

Most of the Earth's surface, both sea and land (about 80\%) is from time to time or always cold, where the temperature is under $5{ }^{\circ} \mathrm{C}$. This makes the low temperatures the most widespread 'extreme' environment of the biosphere [1, 2]. Although the habitats that are mostly or permanently frozen are, as a rule, considered uninhabitable, psychrophilic organisms capable of living in such conditions exist, and are the most abundant, diverse and widespread extremophiles on Earth [3-5].

There is a huge number of lakes (more than 50 millions), including mountain freshwater ecosystems and high-latitude temperate and boreal lakes, which are seasonally covered with ice for most of the year [6, 7]. Despite this, the life that exists under the freshwater ice is one of the least studied aspect of the winter limnology and has to be thoroughly assessed [8-12]. The cold season affects the ecology and metabolic peculiarities of freshwater microorganisms as well as their role in the food web and global biogeochemical cycles throughout the year [13, 14]. The assumption that the cold season is a 'season of rest' [15] and the total biological activity under ice is insignificant, especially in high-latitude ecosystems with thick snow cover, is currently being revised. Studies of lakes with seasonal ice cover apparently demonstrate that the winter food webs and physical processes are active and complex $[7,9,11,16]$.

Low temperatures, low light intensity and limited uptake of nutrients under ice cover affect the rate of biological reactions, microbial activity and, as consequence, microbial diversity [13,17-20]. Although the lakes with seasonal ice cover have not been yet well studied, there is more evidence that the dynamics of the microbiome during the cold season is an important factor for understanding continuity of bacterial community into the next period. The ice cover considerably affects incoming solar radiation and physical processes under ice [21]. Over time, there can form abrupt physical and chemical gradients and functionally and taxonomically different microbial communities that will serve as an 'inoculum' for the next season of open water [11].

Technologies of high-throughput sequencing (HTS) open up opportunities for obtaining more information on diversity, distribution, and dynamics of bacteria and other organisms of the food web in temperate and boreal lakes. These data are limited by late spring and summer due to technical restrictions, and only a small part of such studies deals with microbial communities under ice. The temperate oligotrophic Lake Stechlin (Germany) was investigated for the composition and activity of under-ice heterotrophic bacteria during the decay of blooming cyanobacteria Aphanizomenon flosaquae [22]. The taxonomic composition, richness, and dynamics of bacterial communities on the bottom ice surface and in the water column under the ice were studied during the peak of bloom of dominating complex of plankton in the oligotrophic Lake Baikal [23-26], and the genomes of Baikal subglacial bacteria were assembled [27]. Seasonal dynamics of the microbial community structure during ice formation and after as well as the bacterial carbon cycle were demonstrated for the Great Lakes $[13,28]$. Genome diversity and metabolic activity of Verrucomicrobia was described under ice in lakes of temperate and boreal regions of Quebec, Canada [29]. The relationship of the microbial community structure with physical (water clarity) and chemical parameters (dissolved organic carbon, dissolved oxygen, total nitrogen, and conductivity) of waterbodies was assessed in the arctic lakes of West Greenland [30] and organic matter in a cryogenic lake of the subarctic area of Quebec, Canada [31].

Our research focused on the lakes Labynkyr and Vorota, which are located in one of the coldest places of our planet near the Pole of Cold of the northern hemisphere. This is a continental subarctic dry climate with extremely severe winter and a long ice period that lasts more than 240 days a year. The microbial communities of these extremely cold habitats are still poorly studied due to the uninhabitability of the lake shores and the inaccessibility of the lakes by transport. Recently, we investigated microalgae and showed a high diversity and unique composition of diatoms [32-35]. These investigations are useful for understanding the biogeography and history of formation of the fauna of arctic and subarctic waters. Here we studied bacterial communities inhabiting the lakes that are covered with ice for most of the year. Our aims were to (1) identify the main taxa of bacterial communities during the cold season; (2) evaluate the dynamics of diversity during the ice formation; (3) understand the influence of environmental parameters (thickness of ice and snow cover, temperature, microalgae bloom, and availability of nutrients) on the structure of bacterial communities. The bacterial communities from these extremely cold habitats were described for the first time. This study gave a unique opportunity to get data on the

Page $2 / 15$ 
microbial ecology of frozen lakes in a pristine uninhabited region free of anthropogenic stress. These data may be used as a sensitive indicator of environmental changes and ecological status of lakes.

\section{Materials And Methods}

\section{Study site, sampling and environmental parameters}

Lake Labynkyr (LL) is located at the meeting of the Suntar-Khayata Range and the Oymyakon Highland in the catchment area of the Indigirka River at an altitude of $1020 \mathrm{~m}$ above sea level. Lake Vorota (LV) is located at an altitude of $1014 \mathrm{~m}, 23 \mathrm{~km}$ eastward of Lake Labynkyr (Fig. 1). The cold season lasts from the late October to the middle of June. During this time, the lakes remain frozen and are covered with $40-60 \mathrm{~cm}$ of snow cover. The mean annual temperature varies between -4 and $-16^{\circ} \mathrm{C}$, while in January it goes below $-40^{\circ} \mathrm{C}$, and the lowest recorded temperature is $-71.2^{\circ} \mathrm{C}$. Water temperature is always relatively low, being 1 to $4{ }^{\circ} \mathrm{C}$ in the cold season, and not exceeding $9{ }^{\circ} \mathrm{C}$ in June.

Samples were taken in the northern (L1), central $(\mathrm{L} 2, \mathrm{~L} 3)$ and southern ( $\mathrm{L} 4)$ parts of Lake Labynkyr, and in the central (V1) and northern (V2) parts of Lake Vorota (Fig. 1) in April-May 2016 and in June 2017 (Table 1). Samples (V= 2 L) from the bottom surface of the ice were taken by divers with syringes, while those from water column ( $5 \mathrm{~m}$ depth) were obtained using the Niskin bottle. The list of samples from the bottom surface of the ice (SI) and water column (WC) is given in the Supplement (Table S1). Thickness of ice and snow cover, water temperature $\left(\mathrm{T}^{\circ} \mathrm{C}\right)$ under ice and in water column, $\mathrm{pH}$ and $\mathrm{O}_{2}$ concentration (DO) were measured immediately after sampling. Water electrical conductivity (EC ${ }^{25}$ ) was measured by means of a conductivity meter equipped with a thermal compensation sensor, the conductivity value is normalized by $25^{\circ} \mathrm{C}$. Samples for determining concentrations of silicon (Si), phosphate $\left(\mathrm{PO}_{4}{ }^{3+}\right)$, nitrite $\left(\mathrm{NO}_{2}{ }^{-}\right)$, nitrate $\left(\mathrm{NO}_{3}{ }^{-}\right)$, ammonium $\left(\mathrm{NH}_{4}{ }^{+}\right)$, sum of $\mathrm{N}_{\text {min }}\left(\mathrm{N}-\mathrm{NO}_{3}+\mathrm{N}-\mathrm{NH}_{4}+\mathrm{N}-\mathrm{NO}_{2}\right)$, total dissolved solids (TDS) and total organic carbon (TOC) were frozen at $-20{ }^{\circ} \mathrm{C}$ and transported to the laboratory. All measurements of concentrations of major ions and DOC were performed as previously described [26, 32].

Table 1

Characteristics of the sampling site

\begin{tabular}{|c|c|c|c|c|c|c|c|c|c|c|c|c|c|}
\hline \multirow{2}{*}{$\begin{array}{l}\text { Sampling } \\
\text { site }\end{array}$} & \multicolumn{10}{|c|}{ Lake Labynkyr } & \multicolumn{3}{|c|}{ Lake Vorota } \\
\hline & \multicolumn{3}{|l|}{ L1 } & L2 & \multicolumn{3}{|l|}{ L3 } & \multicolumn{3}{|l|}{ L4 } & \multicolumn{2}{|l|}{ V1 } & V2 \\
\hline \multirow[t]{2}{*}{ Coordinates } & \multicolumn{3}{|c|}{$62^{\circ} 33^{\prime} 33^{\prime \prime} \mathrm{N}$} & $62^{\circ} 30^{\prime} 44^{\prime \prime} \mathrm{N}$ & \multicolumn{3}{|c|}{$62^{\circ} 32^{\prime} 3^{\prime \prime} \mathrm{N}$} & \multicolumn{3}{|c|}{$62^{\circ} 27^{\prime} 14^{\prime \prime} \mathrm{N}$} & \multicolumn{2}{|c|}{$62^{\circ} 25^{\prime} 20^{\prime \prime} \mathrm{N}$} & $62^{\circ} 25^{\prime} 20^{\prime \prime} \mathrm{N}$ \\
\hline & \multicolumn{3}{|c|}{$143^{\circ} 36^{\prime} 27^{\prime \prime} \mathrm{E}$} & $143^{\circ} 34^{\prime} 35^{\prime \prime} \mathrm{E}$ & \multicolumn{3}{|c|}{$143^{\circ} 35^{\prime} 44^{\prime \prime} \mathrm{E}$} & \multicolumn{3}{|c|}{$143^{\circ} 37^{\prime} 26^{\prime \prime} \mathrm{E}$} & \multicolumn{2}{|c|}{$144^{\circ} 06^{\prime} 55^{\prime \prime} \mathrm{E}$} & $144^{\circ} 06^{\prime} 55^{\prime \prime} \mathrm{E}$ \\
\hline $\begin{array}{l}\text { Depth at } \\
\text { the } \\
\text { sampling } \\
\text { point (m) }\end{array}$ & \multicolumn{3}{|l|}{6} & 20 & \multicolumn{3}{|l|}{34} & \multicolumn{3}{|l|}{38} & \multicolumn{2}{|l|}{45} & 30 \\
\hline Time point & $04 / 16$ & $05 / 16$ & $06 / 17$ & $04 / 16$ & $04 / 16$ & $05 / 16$ & $06 / 17$ & $04 / 16$ & $05 / 16$ & $06 / 17$ & $05 / 16$ & $06 / 17$ & $06 / 17$ \\
\hline $\begin{array}{l}\text { Snow cover } \\
\text { thickness } \\
(\mathrm{cm})\end{array}$ & 30 & 5 & 5 & 32 & 30 & 0.5 & 0.5 & 35 & 0.5 & 1 & 1 & 5 & 5 \\
\hline $\begin{array}{l}\text { Ice } \\
\text { thickness } \\
\text { (cm) }\end{array}$ & 91 & 111 & 110 & 86 & 109 & 110 & 80 & 86 & 86 & 86 & 100 & 110 & 110 \\
\hline
\end{tabular}

Water samples were analysed to determine the abundance and biomass of microalgae and bacteria. For quantification of microalgae, $500 \mathrm{~mL}$ of each sample fixed with Lugol's solution was concentrated by settling and siphoning. Microalgae were counted twice using a light microscope Axiostar Plus (Zeiss, Germany) at $\times 20$ and $\times 40$ magnification. The total microalgae abundance of (TMA) was quantified by Kuzmin's method [36]; the total microalgae biomass (TMB) was estimated by the method of Makarova and Pichkily [37]. For identification of microalgae composition, water samples were filtered through $0.8 \mu \mathrm{m}$ filters (Whatman, USA). The filters were then placed on SEM stubs and coated with colloidal gold in an SDC 004 vacuum evaporator (Balzers, Liechtenstein). Samples were examined using a QUANTA 200 scanning electron microscope (FEI Company, Hillsboro, USA). For estimation of total bacterial abundance (TBA), samples were fixed with 2.5\% glutaraldehyde solution and stained with 4, 6-diamidino-2-phenylindole (DAPI), then filtered through 0.22-mm black polycarbonate filters according to the standard protocol [38]. Samples were analysed on an inverted fluorescence microscope Axiovert 200 (Zeiss, Germany).

\section{Isolation and taxonomic identification of cultured bacteria}

Organotrophic psychrotolerant bacteria were cultivated at $4{ }^{\circ} \mathrm{C}$ using fish peptone agar diluted 10 times (FPA:10). All the bacterial strains were subcultured every 3 month and kept at $4{ }^{\circ} \mathrm{C}, 10{ }^{\circ} \mathrm{C}$ and $25^{\circ} \mathrm{C}$. The procedure described in Bashenkhaeva and Zakharova [24] was used for counting the abundance, isolating bacterial strains, extracting DNA, and deriving amplicons of 16S rRNA gene fragments. PCR amplification of the obtained DNA was performed using universal primers for the 16S rRNA gene of eubacteria 27F (AGA GTT TGA TCM TGG CTC AG), 500L (CGT GCC AGC AGC CGC GGT AA) and 1350R (GAC GGG CGG TGT GTA CAA G) [39, 40]. Sequencing was performed using a BigDye 3.1 (Applied Biosystems, USA), while 
analysis was performed by means of a Genetic Analyser 3130XL (Applied Biosystems, USA) in the Genomics Core Facility, Institute of Chemical Biology and Fundamental Medicine, Siberian Branch of the Russian Academy of Sciences, Novosibirsk, Russia. The obtained nucleotide sequences were analysed via Sequence Scanner v1.0 (Applied Biosystems, USA), BioEdit 7.2.5 [41], BLASTN software, and GenBank database. The phylogenetic tree was built using the neighbour-joining method based on Kimura two-parameter algorithm (bootstrap 1000 replicates) in MEGA version 6 software [42]. The sequences were published under the GenBank accessions (MW007890-MW007915).

\section{Microbial sample collection and DNA extraction}

For DNA analyses, approximately $1.5 \mathrm{~L}$ of each sample was first filtered through a $27-\mu \mathrm{m}$ mesh and then through $0.2 \mu \mathrm{m}$ polycarbonate membrane (Whatman, USA). Material was washed from the filters into sterile flasks filled with $5 \mathrm{~mL}$ of TE buffer (10 mM Tris- $\mathrm{HCl}, 1 \mathrm{mM} \mathrm{EDTA}$; pH 7.5$)$, stored and transported at $-20^{\circ} \mathrm{C}$ to the laboratory where the samples were stored at $-80^{\circ} \mathrm{C}$ until further analysis. DNA was extracted using lysozyme ( $\left.1 \mathrm{mg} / \mathrm{mL}\right)$, proteinase K, 10\% SDS and phenol:chloroform:isoamyl alcohol mixture (25:24:1) according to the protocol based on Rusch et al. [43].

\section{Sequencing of V3-V4 16S Metagenomic Libraries}

Purified genomic DNA was sent to Evrogen (Moscow, Russia) for amplicon library preparation and sequencing the V3-V4 variable region of 16S rRNA gene was amplified with primer pair U341F (5'-CCTACGGGRSGCAGCAG-3') and U785R (5'-GGACTACCVGGGTATCTAAKCC-3') [44]. Sequencing was performed using the Illumina MiSeq Sequencer as described in "Illumina 16S Metagenomic Library Preparation Guide \#15044223 Rev. B".

\section{Sequencing data and statistical analyses}

Analysis of sequencing data was performed in Usearch v.10 [45]. Sequences were clustered at 0.97 identity threshold to generate operational taxonomic units (OTUs). The number of reads in samples was normalized. OTU consensus sequences were taxonomically classified using Silva v.138 in Mothur v.1.43.0. The rarefaction curves, observed species richness, Chao1 index (non-parametric species richness estimators), Shannon and Simpson indices (a combination of richness and evenness) were calculated to measure the alpha diversity. Exploratory analysis of community composition and constrained ordination ware performed in R using vegan v.2.5-6 [46], phyloseq [47] and pvclust [48]. First, OTUs having abundance above 0.3\% were selected to produce a count matrix with 58 OTUs. OTU counts were transformed with $\log (x+1)$ and subjected to principal component analysis (transformation-based PCA). Linear regression of exploratory variables was performed by the evnfit function of package vegan. The distance matrix computed with Bray-Curtis similarity index was used for clustering by UPGMA. A robustness of clustering dendrogram was accessed by bootstrap- and au-values in the pvclust package. Transformation-based redundancy analysis was used to evaluate an impact of environmental factors to species composition. Exploratory variables were chosen by a "forward selection" approach. The DESeq2 package [49] was used to evaluate the significance of OTU abundance differences between the groups of samples. The bottom annotation block in Fig. 4 has a detailed explanation of groupings used in the analysis. For each contrast, a subset of phyloseq objects were transformed to DESeq2 objects, followed by estimation of a size factors with geometric means of OTU counts, "local” dispersion estimate, and computation of Wald-test statistics. For testing of OTU differential abundance, the FDR-adjusted $p$-value and log-fold change (LFC) thresholds were set to 0.05 and $\log _{2}(1.5)$, respectively.

\section{Nucleotide Sequence Accession numbers}

The sequence data were submitted to the Sequence Read Archive database (https://www.ncbi.nlm.nih.gov/sra/) of the National Center for Biotechnology Information under accession number PRJNA573475 and PRJNA575317.

\section{Results}

\section{Environmental characterization}

Ice bottom (SI) and water column (WC) samples from Lake Labynkyr (LL) and Lake Vorota (LV) were collected and analysed during three ice-cover periods in April through May 2016 and June 2017 (Table 1). Both lakes were 100\% covered with snow, and its thickness in April was $30 \mathrm{~cm}$, while in May-June it varied between 1 and $5 \mathrm{~cm}$. The ice thickness in the sampling sites varied between 86 and $111 \mathrm{~cm}$. The ice in April and May was solid and transparent, while in June it became acicular and dark. Ice bottom sampling was not performed in June, because the ice was impregnated with water. Water temperature near the ice bottom varied between 0.4 and $1.2^{\circ} \mathrm{C}$. A water temperature of $1.2-3.6^{\circ} \mathrm{C}$ recorded in water column of the northern and central parts of $\mathrm{LL}$ was lower compared to that in the southern part of the lake, $3.7-5.6^{\circ} \mathrm{C}$. Water temperature in $\mathrm{LV}$ did not exceed $3.2^{\circ} \mathrm{C}(\mathrm{Table} 2)$. The $\mathrm{pH}$ values in April were weakly alkaline, 7.70-8.28, and in May they shifted to more alkaline range 7.81-9.34, and were neutral in June, 6.80-7.21. Dissolved oxygen values were stable between $6.7 \mathrm{mg} / \mathrm{L}$ and $10.6 \mathrm{mg} / \mathrm{L}$. 
Table 2

Physical, chemical and biological characteristics of samples

\begin{tabular}{|c|c|c|c|c|c|c|c|c|c|c|c|c|c|c|}
\hline $\begin{array}{l}\text { Time } \\
\text { point }\end{array}$ & Sample & $\begin{array}{l}\mathrm{T} \\
{ }^{\circ} \mathrm{C}\end{array}$ & $\mathrm{pH}$ & $\begin{array}{l}\text { EC } \\
\mu \mathrm{S} / \mathrm{cm}\end{array}$ & $\begin{array}{l}\mathrm{DO} \\
\mathrm{mg} / \mathrm{L}\end{array}$ & $\begin{array}{l}\mathrm{PO}_{4}{ }^{3-} \\
\mathrm{mg} / \mathrm{L}\end{array}$ & $\begin{array}{l}\mathrm{NH}_{4}^{+} \\
\mathrm{mg} / \mathrm{L}\end{array}$ & $\begin{array}{l}\mathrm{NO}_{2}^{-} \\
\mathrm{mg} / \mathrm{L}\end{array}$ & $\begin{array}{l}\mathrm{NO}_{3}{ }^{-} \\
\mathrm{mg} / \mathrm{L}\end{array}$ & $\begin{array}{l}N_{\text {min }} \\
\mathrm{mg} / \mathrm{L}\end{array}$ & $\begin{array}{l}\text { TDS } \\
\mathrm{mg} / \mathrm{L}\end{array}$ & $\begin{array}{l}\text { TOC } \\
\text { mgC/L }\end{array}$ & $\begin{array}{l}\text { TMA } \times 10^{3} \\
\text { cells/L }\end{array}$ & $\begin{array}{l}\text { TMB } \\
\mathrm{g} / \mathrm{m}^{3}\end{array}$ \\
\hline \multirow{6}{*}{ April } & L1WC04 & 1.2 & 7.84 & 43.22 & 10.6 & 0.003 & 0.059 & 0.002 & 0.30 & 0.12 & 29.29 & 2.58 & 13.70 & 0.03 \\
\hline & L2SI04 & 1.2 & 7.71 & 45.98 & 7.5 & 0.001 & 0.062 & 0.002 & 0.34 & 0.13 & 31.82 & 2.88 & 24.10 & 0.06 \\
\hline & L3SI04 & 0.4 & 7.55 & 44.92 & \multirow[t]{2}{*}{8.9} & 0.001 & 0.014 & 0.002 & 0.33 & 0.08 & 30.72 & 3.45 & 20.95 & 0.02 \\
\hline & L3WC04 & 1.9 & 7.93 & 39.49 & & 0.002 & 0.058 & 0.001 & 0.29 & 0.11 & 26.67 & 2.21 & 28.85 & 0.03 \\
\hline & L4SI04 & 0.4 & 7.48 & 50.1 & \multirow[t]{2}{*}{8.2} & 0.004 & 0.019 & 0.001 & 0.42 & 0.11 & 33.96 & 3.04 & $40.40-$ & 0.04 \\
\hline & L4WC04 & 3.7 & 7,70 & 39.85 & & 0.001 & 0.069 & 0.002 & 0.28 & 0.12 & 26.54 & 3.04 & 39.55 & 0.13 \\
\hline \multirow{6}{*}{ May } & L3SI05 & 1.2 & 7.81 & 23.34 & \multirow[t]{2}{*}{9.8} & 0.006 & 0.007 & 0.003 & 0.19 & 0.05 & 17.16 & 1.99 & 34.40 & 0.03 \\
\hline & L3WC05 & 3.4 & 9.26 & 40.76 & & 0.002 & 0.016 & 0.001 & 0.20 & 0.09 & 27.71 & 2.66 & 313.67 & 0.03 \\
\hline & L4SI05 & 1.3 & 6.97 & 8.517 & \multirow[t]{2}{*}{9.6} & 0.000 & 0.009 & 0.002 & 0.17 & 0.05 & 6.56 & 1.50 & 52.56 & 0.06 \\
\hline & L4WC05 & 3.7 & 9.20 & 41.53 & & 0.007 & 0.012 & 0.002 & 0.33 & 0.08 & 28.47 & 1.28 & 227.78 & 0.07 \\
\hline & V1SI05 & 0.4 & 8.94 & 41.48 & \multirow[t]{2}{*}{8.5} & 0.008 & 0.001 & 0.003 & 0.10 & 0.02 & 31.74 & 1.24 & 192.7 & 0.03 \\
\hline & V1WC05 & 3.1 & 8.82 & 51.21 & & 0.012 & 0.004 & 0.000 & 0.08 & 0.02 & 42.47 & 0.86 & 79.55 & 0.08 \\
\hline June & L1WC06 & 3.6 & 6.80 & 30.89 & 8.3 & 0.003 & 0.017 & 0.003 & 0.33 & 0.09 & n.d. & 1.05 & 173.3 & 0.02 \\
\hline
\end{tabular}

Phosphate, nitrite, nitrate and total nitrogen concentrations in SI samples did not considerably differ from those in WC samples. Phosphate concentrations in April did not exceed $0.004 \mathrm{mg} / \mathrm{L}$ in $\mathrm{LL}$, in May and June they increased to $0.009 \mathrm{mg} / \mathrm{L}$ and $0.016 \mathrm{mg} / \mathrm{L}$ respectively. In LV they remained within $0.008-0.024 \mathrm{mg} / \mathrm{L}$. Nitrite concentrations in all samples did not exceed $0.006 \mathrm{mg} / \mathrm{L}$. Nitrate concentrations in LL were between 0.17 $\mathrm{mg} / \mathrm{L}$ and $0.45 \mathrm{mg} / \mathrm{L}$, exceeding those in $\mathrm{LV}$, which were in the range of $0.04-0.10 \mathrm{mg} / \mathrm{L}$. Ammonium ion content in WC samples was equal to $0.058-$ $0.069 \mathrm{mg} / \mathrm{L}$ in April and 0.004-0.017 mg/L in May-June, and was higher than in SI samples. The lakes have a low salt content; the sum of main ions did not exceed $33.96 \mathrm{mg} / \mathrm{L}$ in LL and $42.47 \mathrm{mg} / \mathrm{L}$ in LV. Organic matter indicators varied between $0.75 \mathrm{mgC} / \mathrm{L}$ and $3.26 \mathrm{mgC} / \mathrm{L}$; they were higher in April than in May and June.

LL phytoplankton included Bacillariophyta, Chrysophyta, Dinophyta, Haptophyta, Cryptophyta, and Chlorophyta species, and the biomass of algae was in the range 0.01 to $0.13 \mathrm{~g} / \mathrm{m}^{3}$. Small centric diatoms Pantocsekiella costei (J.C. Druart \& F.Straub) K.T.Kiss \& E.Ács were the most abundant in all samples (65-90\%), while larger diatoms Lindavia minuta were within 5\%. Bacillariophyta and Cryptophyta species dominated LV phytoplankton; the biomass of algae varied between 0.02 and $0.08 \mathrm{~g} / \mathrm{m}^{3}$. Diatoms P. costei and Lindavia ocellata (Pantocsek) T.Nakov et al. prevailed in all samples; Lindavia minuta (Skvortsov) T.Nakov et al. was about $20 \%$ of the total number in May, while in June the contribution of cryptophytic Rhodomonas pusilla (H.Bachmann) Javornicky was in the range 10 to $50 \%$.

\section{Richness, diversity and bacterial community composition}

2177 OTUs (97\% similarity) from 997349 quality-filtered, chimera-free, paired sequences obtained from 21 samples (47517 reads in average in a sample, mean length 455 bps) were identified in total. Rarefaction curves built for all samples at a genetic distance of 0.03 reached the saturation, indicating that the bacterial diversity was sufficiently embraced (Fig. S1). The number of OTUs and the values of taxonomic richness (Chao1) and diversity (Shannon and Simpson) indices of the communities were higher in LL than in LV, with higher values being found in water column of the northern (L1WC05, L1WC06) and southern parts of LL (L4WC06) in May and June. In total, the number of OTUs in SI and WC communities was similar (406-465) in April; in May and June, it was higher in WC (535-1301) than in SI (439-600) (Table 3). 
Table 3

Non-parametric alpha diversity metrics calculated for the bottom surface of the ice and water column samples collected from lakes Labynkyr and Vorota over three sampling dates

\begin{tabular}{|c|c|c|c|c|c|c|}
\hline $\begin{array}{l}\text { Time } \\
\text { point }\end{array}$ & Samples & Reads & Richness (OTU) & Chao1 & Simpson & Shannon \\
\hline \multirow[t]{8}{*}{ April } & L1SI04 & 47504 & 431 & 431.0 & 0.0286 & 4.31 \\
\hline & L1WC04 & 47535 & 424 & 424.0 & 0.041 & 4.11 \\
\hline & L2SI04 & 47512 & 433 & 433.0 & 0.0268 & 4.32 \\
\hline & L2WC04 & 47508 & 417 & 417.0 & 0.0217 & 4.52 \\
\hline & L3SI04 & 47513 & 406 & 406.0 & 0.0238 & 4.41 \\
\hline & L3WC04 & 47488 & 465 & 465.7 & 0.0286 & 4.35 \\
\hline & L4SI04 & 47453 & 434 & 435.9 & 0.0269 & 4.37 \\
\hline & L4WC04 & 47468 & 464 & 464.9 & 0.018 & 4.61 \\
\hline \multirow[t]{7}{*}{ May } & L1SI05 & 47485 & 439 & 440.4 & 0.054 & 3.85 \\
\hline & L1WC05 & 47449 & 1301 & 1301.3 & 0.0371 & 4.86 \\
\hline & L3SI05 & 47491 & 600 & 606.4 & 0.182 & 3.16 \\
\hline & L3WC05 & 47519 & 568 & 569.2 & 0.0254 & 4.51 \\
\hline & L4SI05 & 47558 & 379 & 381.2 & 0.393 & 1.82 \\
\hline & V1SI05 & 47513 & 409 & 410.2 & 0.0902 & 3.44 \\
\hline & V1Wc05 & 47474 & 447 & 448.1 & 0.0338 & 4.13 \\
\hline \multirow[t]{6}{*}{ June } & L1WC06 & 47632 & 1022 & 1023.7 & 0.133 & 3.21 \\
\hline & L3WC06 & 47534 & 535 & 536.2 & 0.0482 & 4.01 \\
\hline & L4WC06 & 47729 & 1253 & 1253.0 & 0.0232 & 4.98 \\
\hline & V1Wc06 & 47459 & 509 & 513.9 & 0.102 & 3.35 \\
\hline & V1SI06 & 47521 & 392 & 393.8 & 0.0928 & 3.15 \\
\hline & v2WC06 & 47504 & 342 & 345.7 & 0.130 & 2.82 \\
\hline
\end{tabular}

All OTUs were distributed by 15 phyla, about $3 \%$ of all sequences belonged to unclassified Bacteria. The bacterial phyla, to which the most sequences had been attributed, included Proteobacteria (OTUs, 59\%) and Actinobacteriota (OTUs, 11\%). It is noteworthy that the abundance of Proteobacteria was represented mainly by Gammaproteobacteria and Alphaproteobacteria was relatively even in all communities, while the abundance of Actinobacteriota dramatically decreased in all communities of both lakes in June, compared with April and May (Fig. 2). Other abundant phyla that had a different distribution among the communities included Planctomycetota (OTUs, 6\%), Cyanobacteria (OTUs, 5\%), Bacteroidota (OTUs, 4\%), Verrucomicrobiota (OTUs, 4\%), and Patescibacteria (OTUs, 3\%). These taxa were relatively evenly abundant in April in all communities. In May and June, Planctomycetota were decreased, while Bacteroidota and Verrucomicrobiota were more abundant. Cyanobacteria were the most abundant in all LV communities, while the Patescibacteria species was found in quantity in several LL water column communities (Fig. 2). Distribution of Acidobacteriota, Bdellovibrionota, Chloroflexi, Dependentiae, and Firmicutes phyla were within $1 \%$ of all sequences, and also differed depending on community.

\section{Community structure relationships}

Exploratory analysis revealed a high intra-group similarity of April and May LL communities as well as an isolated position of LV samples (Fig. 3). June LL communities formed a more diffuse cluster. According to the analysis, L4SI05 and L3SI05 communities were excluded from the sampling when quantifying the number of OTUs by sampling time. LV communities are divided in two groups: the first includes V1SI06 and V2WC06 (group June), the second unites three remaining samples V1WC06, V1SI05 and V1WC05 (group May). Heat map clustering results (Fig. 4) confirm that April LL communities are similar. The analysis of dissimilarity of OTU number among samples of this group revealed only Moraxellaceae (OTU27 Acinetobacter) and Sphingomonadaceae (OTU49 Sphingobium) were more abundant in WC samples than in samples from communities at the icewater interface (SI samples).

The most significant dissimilarities are observed between bacterial communities are taken in April and June LL (Fig. 4). For example, OTUs taxonomically affiliated to chloroplast-specific sequences, Comamonadaceae(Curvibacter, Acidovorax), Cyanobiaceae(Cyanobium_PCC-6307), 
uncultured Methylacidiphilaceae, Mycobacteriaceae (Mycobacterium), uncultured Pirellulaceae, and uncultured Gaiellales were significantly more abundant in June. OTUs affiliated to Burkholderiaceae (Polynucleobacter), Chthoniobacteriaceae (Chthoniobacter), Comamonadaceae (Limnohabitans), Ilumatobacteraceae(CL500-29_marine_group), Moraxellaceae(Acinetobacter), Sporichthyaceae(Candidatus_Planktophila, hgcl_clade), Burkholderiales (TRA3-20) were less abundant in June then in April (Table S2). Oxalobacteraceae (Massilia) have a similar temporal dynamics when comparing LL communities in April/May and April/June, their abundance increases in end spring and early summer.

May/June and April/June LL communities demonstrated a similar pattern of changes, though the list of differentially abundant OTUs and the range of abundance differences was slightly less pronounced (Fig. 4, Table S2). OTUs affiliated to uncultured Pirellulaceae and uncultured Gaiellales were found mainly in June, while Polynucleobacter, Chthoniobacter, SAR11, Limnohabitans, unclassified Comamonadaceae, Ilumatobacteraceae (CL500-

29_marine_group), and Acinetobacterwere significantly more abundant in in May. Within LV communities Sporichthyaceae and Ilumatobacteraceae were abundant in May, while Beijerinckiaceae (Methylobacterium-Methylorubrum) had the opposite dynamics. Comparative analysis of the distribution of the most abundant OTUs also suggests differences in OTU abundance across the LL and LV communities. OTUs belonged to unclassified Beijerinckiaceae, Burkholderiaceae (Polynucleobacter), Chthoniobacteraceae, (Chthoniobacter), Moraxellaceae (Acinetobacter), uncultured Pirellulaceae, and Pseudomonadaceae (Pseudomonas) were more abundant in LL communities, while chloroplast-specific sequences, Cyanobiaceae (Cyanobium_PCC-6307), Ilumatobacteraceae (CL500-29_marine_group), uncultured Methylacidiphilaceae, uncultured Oligoflexales, and uncultured Gaiellales were found mainly in LV communities (Fig. 4, Table S2).

\section{Effect of the environmental factors on community composition}

We studied the correlation between the structure of bacterial communities and different environmental parameters, such as thickness of snow mantle, water temperature, $\mathrm{pH}, \mathrm{EC}^{25}, \mathrm{DO}, \mathrm{PO}_{4}{ }^{3-}, \mathrm{NH}_{4}{ }^{+}, \mathrm{NO}_{3}{ }^{-}, \mathrm{NO}_{2}{ }^{-}, \mathrm{N}_{\min }, \mathrm{TOC}, \mathrm{TMA}$ and TMB. According to the results of transformation-based RDA, the important exploratory variables were the thickness of snow mantle $\left(\mathrm{R}^{2}\right.$ adj $\left.=0.19, p=1.3 \mathrm{E}-3\right), \mathrm{pH}\left(\mathrm{R}^{2}\right.$ adj $\left.=0.11, p=2 \mathrm{E}-3\right)$, conductivity $\left(\mathrm{R}^{2}\right.$ adj $=0.11, p=$ 1.3E-3), and total nitrogen concentration $\left(\mathrm{R}^{2}\right.$ adj $\left.=0.10, p=1.3 \mathrm{E}-3\right)$ (Fig. 5a). The proportion of the total variation explained by these four variables is $\sim$ $70 \%$, which is rather high. The grouping pattern revealed by the constrained ordination approach is very similar to that of the unconstrained approach (Fig. 3a). Variance partitioning (Fig. 5b) shows almost no overlap between the model variables except snow thickness and total nitrogen. The latter fact highlights that snow thickness and TN are autocorrelated considerably.

\section{Cultivated organotrophic bacteria}

The total number of microorganisms in the lakes was not high, $0.2-1.0 \times 10^{6}$ cells $/ \mathrm{mL}$, and the quantity of cultivable bacteria varied between 10 to 330 $\mathrm{CFU} / \mathrm{mL}$. Forty-nine strains were isolated from the under-ice communities of the lakes. Twenty-six strains with different morphological characteristics were chosen for taxonomical identification via the phylogenetic analysis of 16S rRNA gene. The resulting sequences of the cultivable strains were attributed to Proteobacteria, Actinobacteria, Bacteroidetes, and Firmicutes (Fig. 6). More than half of the sequences had a high similarity (99-100\%) with bacterial sequences from cold habitats (Table S3). The genus Pseudomonas represented by seven species (Ps. gramilis, Ps. fragi, Ps. antarctica, Ps. collierea, Ps. yamanorum, Ps. tolaasy and Ps. fluorescens) dominated among Proteobacteria. In addition, Proteobacteria were represented by strains closely related to Janthinobacterium (J. lividum), Rahnella (R. aquatilis), Serratia (S. myotis). Actinobacteria belonged to the genera Micrococcus (M. yunnanensis) and Rhodococcus, their sequences were attributed to three species: $R$. cerastii, $R$. fascians, and $R$. qingshengi. Bacteriodetes species were from the genera Chryseobacterium and Pedobacter (P. terrae). Firmicutes was represented by a sole strain Paenibacillus amylolyticus.

\section{Discussion}

We have to note that these lakes are of interest for investigations because they are classified as a "unique lake" of the protected areas of Yakutia. These territories received this status for preservation of unique natural complexes and objects, biological resources and their genetic diversity, and for the study of global biosphere processes and control of their changes [50]. For the first time, we studied microbial communities of LL and LV located in an extremely cold place of the northern hemisphere using the HTS method and phylogenetic analysis of cultivable strains. In total, our study shows astonishing differences in the diversity and composition of bacteria both on ice bottom and in water column at different time points (April, May, June) during the ice-cover period in both lakes. The microbial community present under the ice showed progressive changes in accordance with previous studies, demonstrating an active accretion of microbial communities and changes of bacterial communities during the ice-cover period $[11,13,17,28]$.

\section{Lake conditions}

The environmental parameters during this period were relatively stable. Water temperature $\left(1^{\circ} \mathrm{C}\right.$ at $\mathrm{Sl}$, not more than $5.6^{\circ} \mathrm{C}$ in WC) and concentrations of nutrients and organic matter were quite low (Table 2). Dissolved oxygen in the surface water layer was in the range of 6.7-10.6 $\mathrm{mg} / \mathrm{L}$ (49-78\% saturation), suggesting that surface water was oxygenated enough and thus allowed the dominance of aerobic processes during the long ice-cover period. These days, the turnover of the ultraoligotrophic lakes mostly depends on natural factors such as permafrost soil, additional runoff from adjacent lands due to intensive thawing, and erosion of surface soil as well as water replenishment from snow and rain. The lakes are considered a low carbon environment due to the long ice-cover period that disturbs the input of organic matter from the atmosphere and land, and diminishes the primary productivity because of low light levels under ice. These conditions explain the low salt and nutrient content in the lakes during the warm and cold season [32]. 
Microalgae also actively developed within the under-ice microbial communities. We recorded a rapid more than 10 -fold increase in the number of diatoms and cryptophytic algae (Table 2) during one month from April to May. In June, with the ice melt, the abundance of microalgae was average. We had previously shown the high richness of the lake microflora [34, 35, 51]. Its diversity starts increasing under ice and reaches the maximum in summer during the open water period. Nonetheless, more than $80 \%$ of cold-adapted taxa found during the under-ice period kept growing in summer phytoplankton and periphyton [33]. Such development of under-ice algal bloom coincides with observations described in previous papers [11, 23, 52, 53].

\section{Distribution and diversity of bacterial communities}

We observed a persistently high diversity and richness of LL bacterial communities in April; their values (Chao1, Shannon) became even higher (Table 3) in some communities in May and June, although the quantity of microorganisms in under-ice communities remained low. The maximal diversity was found in the southern and northern parts of LL, near the places where the Labynkyr River flows in and out (Fig. 1). As it has been previously shown, bacterial communities in seasonally frozen river ecosystems resort to different ecological strategies, such as metabolic flexibility and morphological variability. This enlarges species diversity and richness during the cold season in comparison with warm one [54]. It is thus likely that the growth of biodiversity can be induced by mixture of river and lake waters. We do not know whether this diversity persists during open water period in the warm season or decreases according to other studies. Butler et al. [28] suggest that increasing temperature and concentrations of nutrients during the warm season allow the dominance of individual taxa in the system, while the growth of warm-adapted microorganisms is inhibited during ice-cover period. The nutrients thus became more available for other organisms, thereby facilitating development of a more diverse community.

Our findings demonstrated that the composition of dominating bacterial taxa was similar not only to other freshwater ecosystems during ice-cover period, but they also revealed some peculiarities in their diversity and abundance. Our data and scientific literature indicate that Proteobacteria, Actinobacteriota, and Bacteroidetes usually abound in the ecosystems covered with ice $[27,30,55,56]$. The lakes we studied allow tracing a difference in distribution of dominating taxa in different time points (Fig. 3). Relative contributions of eight the most abundant families of $y$-Proteobacteria were found even in all April samples, while in May and June most OTUs belonged to Comamonadaceae, Oxalobacteraceae, and Diploricketsiaceae. It should be noted that y-Proteobacteria were more successful in LL and LV unlike Bacteroidetes (Chitinophagaceae, Flavobacteriaceae) [22, 23, 57] and Verrucomicrobia (Methylacidiphilaceae, Chthoniobacteraceae) $[27,29]$ that are widespread and usually dominate under-ice communities of freshwater ecosystems. Actinobacteria were represented mostly by Sporichthyaceae and Ilumatobacteraceae, and they prevailed in both lakes during the stable ice period (April, May). When the ice became acicular (June), their contribution to the communities noticeably diminished. Such a sharp difference was surprising, especially taking into account that Actinobacteria are, as a rule, a constant abundant taxon in freshwater communities [58], including those living under ice and in open water immediately after ice melt [23-26, 31, 59-61]. Planctomycetota, whose abundance decreased a little in June, gave a relatively large contribution to the composition of the bacterial communities. Planctomycetota species occur quite often in lakes covered with ice [27], but are typically less abundant members of a community [22, 28, 55]. Nonetheless, as it was previously reported [31], Planctomycetota dominated in winter communities of a cryogenic lake in the sporadic permafrost zone of subarctic Quebec, while their genomic bins contained a significant potential for degradation of organic matter (cellulose, starch, xylan and pectin) due to the presence of multiple genes responsible for degradation of carbohydrates. Cyanobacteria, on the contrary, became more abundant in both lakes in May and arrived at their maximum in Lake Vorota in June (Figs. 2, 4); this was most likely due to increasing solar radiation because of a considerable reduction of snow cover thickness and partial ice melt at that time (Table 1). Cyanobacteria, which seem to belong to the species adapted to low temperature and low light intensity, often bloom under ice in temperate lakes [22]. A high abundance of Cyanobacteria including some species known to fix nitrogen was found in High-Arctic snow and freshwater [55]. The authors suggest the nitrogen fixed by Cyanobacteria could stimulate the primary algal production, while carbon and nitrogen produced by autotrophs were feeding heterotrophic bacteria and thus controlling their growth and diversity.

\section{Comparison LL and LV communities}

The beta diversity comparison revealed a clear separation of the communities according to their habitat and time points (Fig. 5). According to our results, the microbial community is not stable during the long ice-cover period, but exposed to continuous change. Our data agree with those obtained during previous studies of ice-covered lakes that showed an active development of their microbial communities and changes in the species composition during the ice-cover period $[18,23,28,62]$. Diversity and composition of bacterioplankton change in time and by sampling sites. It can be also seen on the heat map of the most abundant OTUs (Fig. 4, Table S2), where a change takes place in the dominating taxa in individual communities. Microalgae seem to be a part of this actively growing community in LV. We saw a considerable number of chloroplast sequences in May and their number increased in June in LV though it was still covered with ice; meanwhile these sequences were not numerous in LL. The under-ice bloom of microalgae can cause manifest shifts in the bacterial community structure, as was previously reported during Cyanobacteria blooms [22, 63]. The authors assume that energy and availability of substrate are key factors controlling dynamics of aqueous organisms under ice, and not temperature. Although our study was limited by a short-time interval of a long ice-cover period before ice melting, it was not difficult to see that the under-ice conditions were quite stable. The given change of diversity may not thus depend too much on temperature, concentrations of nutrients, and organic matter as well as on other physical and chemical parameters. This assumption is confirmed by the RDA results, which show that the thickness of snow mantle, $\mathrm{N}_{\text {min }}$, and EC ${ }^{25}$ are important exploratory variables (Fig. 5). This implies that the processes of community development dynamics under ice at this time may include interspecies relationships regulating the composition of the communities. As the example of Cyanobacteria shows, their abundance and diversity increase, while those of Proteobacteria decrease in June communities correlating with thickness of snow cover and EC ${ }^{25}$ value.

\section{Phylogenetic composition of cultivated bacteria}

Page $8 / 15$ 
As we expected, the composition of cultivable bacteria did not reflect the composition found by the HTS method, illustrating the well-known discrepancy between molecular methods of total DNA analysis and cultivation-based methods [55]. Nevertheless, the cultivation method allowed identification of both dominating (Pseudomonas, Janthynobacterium) and minor taxa (Micrococcus, Rhodococcus, Serratia, Pedobacter, Chryseobacterium, Paenibacillus) revealed by the NTS method. Moreover, the cultivation method allowed the species identification of available sequences with a high degree of similarity (99-100\%) to known strains from cold habitats (Table S3). The cultivation method was useful for understanding ecological importance of some phylogenetic groups in extremely cold environments.

The cultivation showed a dominance of Y-Proteobacteria represented by the genus Pseudomonas (Fig. 6). It was not surprising, as Pseudomonas grew well on depleted media and successfully competes in heterotrophic conditions. Pseudomonas is a cosmopolitan genus found in different habitats of cold ecosystems [24, 56, 64-66]. Some Pseudomonas developed different strategies of survival and colonization of extremely cold habitats, including polyunsaturated fatty acid biosynthesis, mRNA chaperones, and other cold-inducible proteins $[67,68]$. The isolation of cultivable Actinobacteria species was also expected, particularly as the HTS results had shown them to be a dominating taxon in the communities. The necessity to use new methods for isolating Actinobacteria from extreme environments had been already emphasized in discussions [69]. Despite metagenome descriptions, the access to cultivable organisms is of crucial importance for identification of the phenotypic features that affect adaptation and survival in an extreme biosphere. A thoroughly selected set of conditions allowed the successful isolation of $80 \%$ of Actinobacteria (all members of the Micrococcineae) of the total number of cultivable bacteria from Spitzbergen permafrost soil [70], and more than $60 \%$ from Greenland glacier ice core [71]. The dominance in a cultivable community and the presence of viable metabolically active Actinobacteria (mostly members of Micrococcineae) in permafrost [72, 73] and glacier samples [71, 74] prove their ecological function in the cryosphere.

The finding of representatives of the genus Janthinobacterium is of great interest, especially as the isolated strains had the strongest resemblance to $\mathrm{J}$. lividum. This bacterial species occurs in soil and water of cold and temperate regions. J. lividum produces violacein, a compound having a diverse biological activity [75] including a strong antimicrobial action against a wide range of important human pathogens [76]. The authors claim that the $J$. lividum ROICE173 strain isolated from arctic snow is promising for the biotechnological industry, oriented to development of new antimicrobial drugs or to reduction of proliferation of multidrug-resistant pathogens into the environment. Bacteria of the phylogenetic lineage of Bacteroidetes were found among the strains attributed to the genera Chryseobacterium and Pedobacter. Bacteroidetes representatives showed to be very abundant in cold freshwater ecosystems, including Antarctica, where they could play special roles in natural carbon cycles consuming and degrading the high molecular mass fraction of dissolved organic matter [56]. This idea is corroborated by finding of isolates and clones able to hydrolyse macromolecules, likely via producing extracellular enzymes $[66,77,78]$. Firmicutes representatives, in particular the genus Paenibacillus, had been isolated from the Greenland Glacier Ice Core [79], snow cover at Spitzberg [80], and the deep Lake Vostok ice core [81]. This confirms their sustainability in the very cold environments.

\section{Conclusions}

We would like to note that the combination of high-throughput sequencing and cultivation methods allowed us to obtain for the first time information about microbial communities of Lake Labynkyr and Lake Vorota, which are covered with ice for long periods of time. Despite the severe conditions and low quantity of microorganisms, we found a high diversity and changes in the richness of the structure of the communities during the ice-cover period. These results may enrich our conception of the under-ice life. Expanding on earlier investigations of ice-covered habitats, we characterized here the microbial communities that are important for understanding their ecological function in aquatic ecosystems, considering that the study area is uninhabited and free of anthropogenic stress. Further, it is necessary to characterize the temporal changes in the composition of microbial communities during a short period of open water in order to better understand how seasonal variations and ice cover affect the ecosystem function.

\section{Declarations}

Acknowledgements The authors acknowledge I. E. Zhullyarov and A. A. Dolzhenkov for organizing the expedition and technical support, and the divers A. S. Gubin, M. V. Astakhov, S. V. Bulochkin and V. I. Chernykh, for their assistance during the field studies.

Author Contributions Ye.L. and L.K. J.C. designed the study. Yu.Z., M.B. and L.K. were involved in the field work. M.B. identified species and cultivated of bacteria. D.P. and A.M. conducted molecular experiments. I.T. conducted chemical analyses. Yu.G. analyzed the data and produced figures. Yu.Z. wrote the manuscript and all authors contributed to revisions.

Funding The work was supported by the State Assignments of the Institute for Biological Problems of Cryolithozone, (No. 0297-2021-0023, 21121012190038-0; expeditions) and of the Limnological Institute (No. 0279-2021-0008, 121032300186-9; analysis) of the Siberian Branch of the Russian Academy of Sciences. The microscopy studies were done in the Electron Microscopy Center of the Shared Research Facilities "Ultramicroanalysis" of Limnological Institute (https ://www.lin.irk.ru/copp/).

\section{Declarations}

Ethics Approval Not applicable.

Consent to Participate Not applicable. 
Consent for Publication All authors agreed with the publication of this manuscript.

Competing interests The authors declare no competing interests.

\section{References}

1. D’Amico S, Collins T, Marx J-C, Feller G, Gerday C (2006) Psychrophilic microorganisms: challenges for life. EMBO Rep 7:385-389.

2. De Maayer P, Anderson D, Cary C, Cowan DA (2014) Some like it cold: understanding the survival strategies of psychrophiles. EMBO Rep 15:508517 https://doi.org/10.1002/embr.201338170

3. Rodrigues DF, Tiedje JM (2008) Coping with our cold planet. Appl Environ Microbiol 74:1677-1686

4. Casanueva A, Tuffin M, Cary C, Cowan DA (2010) Molecular adaptations to psychrophily: the impact of 'omic' technologies. Trends Microbiol 18:374-381

5. Margesin R, Schinner F, Marx JC, Gerday C (2008) Psychrophiles, from Biodiversity to Biotechnology. Springer, Berlin

6. Verpoorter C, Kutser T, Seekell DA, Tranvik LJ (2014) A global inventory of lakes based on high-resolution satellite imagery. Geophys Res Lett 41:6396- https://doi.org/10.1002/2014GL060641

7. Hampton SE, Galloway AWE, Powers SM et al (2017) Ecology under lake ice. Ecol Lett 20:98-101. https://doi.org/10.1111/ele.12699

8. Walsh SE, Vavrus SE, Foley JA, Fisher VA, Wynne RH, Lenters JD (1998) Global patterns of lake ice phenology and climate: Model simulations and observations. J Geophys Res 103:28825-28837. https://doi.org/10.1029/98JD02275

9. Salonen K, Leppa M, Viljanen RM, Gulati RD (2009) Perspectives in winter limnology: Closing the annual cycle of freezing lakes. Aquat Ecol 43:609-616, https://doi.org/1007/s10452-009-9278-z

10. Weyhenmeyer GAD, Livingstone M, Meili M, Jensen O, Benson B, Magnuso JJ (2011) Large geographical differences in the sensitivity of ice-covered lakes and rivers in the Northern Hemisphere to temperature changes. Glob Change Biol 17:268-275. https://doi.org/1111/j.13652486.2010.02249.x

11. Bertilsson S, Burgin A, Carey CC, Fey SB, Grossart HP, Grubisic LM, Jones ID, Kirillin G, Lennon JT, Shade A, Smyth RL (2013) The under-ice microbiome of seasonally frozen lakes. Limnol Oceanogr 58:1998-2012. https://doi.org/10.4319/lo.2013.58.6.1998

12. Powers SM, Hampton SE (2016) Winter Limnology as a New Frontier. Limnol Oceanogr Bull 25:103-108.

13. Wilhelm SW, LeCleir GR, Bullerjahn GS, McKay RM, Saxton MA, Twiss MR, Bourbonniere RA (2014) Seasonal changes in microbial community structure and activity imply winter production is linked to summer hypoxia in a large lake. FEMS Microbiol Ecol 87:475-485.

https://doi.org/10.1111/1574-6941.12238

14. Ricao Canelhas M, Denfeld B A, Weyhenmeyer GA, Bastviken D, Bertilsson S (2016) Methane oxidation at the water - ice interface of an ice-covered lake. Limnol Oceanogr 61:S79-S90

15. Sommer U, Gliwicz ZM, Lampert W, Duncan A (1986) The PEG-model of seasonal succession of planktonic events in fresh waters. Arch. Hyrobiol 106: $433-471$

16. Bruesewitz DA, Carey CC, Richardson DC, Weathers KC (2015) Under-ice thermal stratification dynamics of a large, deep lake revealed by highfrequency data. Limnol Oceanogr 60:347-359.

17. Pernthaler J, Glöckner FO, Unterholzner S, Alfreider A, Psenner R, Amann R (1998) Seasonal community and population dynamics of pelagic bacteria and archaea in a high mountain lake. Appl Environ Microb 64:4299-4306

18. Beall BFN, Twiss MR, Smith DE, Oyserman BO, Rozmarynowycz MJ, Binding CE, Bourbonniere RA, Bullerjahn GS, Palmer ME, Reavie ED, Waters MK, Woityra WC, McKay RML (2016) Ice cover extent drives phytoplankton and bacterial community structure in a large north-temperate lake: implications for a warming climate. Environ Microbiol 18:1704-1719. https://doi.org/10.1111/1462-2920.12819

19. Rogozin DY, Zykov V V, Chernetsky MY, Degermendzhy AG, Gulati RD (2009) Effect of winter conditions on distributions of anoxic phototrophic bacteria in two meromictic lakes in Siberia, Russia. Aquat Ecol 43:661-672. https://doi.org/10.1007/s10452-009-9270-7

20. Villaescusa JA, Casamayor EO, Rochera C, Vela Zquez D, Chicote A, Quesada A, Camacho A (2010) A close link between bacterial community composition and environmental heterogeneity in maritime Antarctic lakes. Int Microbiol 13:67-77

21. Kirillin G, Leppäranta M, Terzhevik A, Granin N, Bernhardt J, Engelhardt C, Efremova T, Golosov S, Palshin N, Sherstyankin P, Zdorovennova G, Zdorovennov R (2012) Physics of seasonally ice-covered lakes: a review. Aquat Sci 74:659-682. https://doi.org/10.1007/s00027-012-0279-y

22. Bižić-lonescu M, Amann R, Grossart H-P (2014) Massive regime shifts and high activity of heterotrophic bacteria in an ice-covered lake. PLoS ONE 9(11):e113611. https://doi.org/10.1371/journal.pone.0113611.

23. Bashenkhaeva MV, Zakharova YR, Petrova DP, Khanaev IV, Galachyants YP, Likhoshway YV (2015) Sub-ice microalgal and bacterial communities in freshwater Lake Baikal. Russia. Microb Ecol 70:751-765. https://doi.org/10.1007/s00248-015-0619-2

24. Bashenkhaeva MV, Zakharova, YuR (2017) Cultivated bacteria from the sub-ice algaebacterial communities of Lake Baikal. Acta Biol Sibirica 3:7685. https://doi.org/10.14258/abs.v3i3.3619

25. Bashenkhaeva MV, Zakharova YuR, Galachyants YuP, Khanaev IV, Likhoshway YeV (2017) Bacterial communities during the period of massive under-ice dinoflagellate development in Lake Baikal. Microbiol 86:524-532. https://doi.org/10.1134/S0026261717040038

Page 10/15 
26. Bashenkhaeva MV, Galachyants YP, Khanaev IV, Sakirko M V, Petrova DP, Likhoshway YeV, Zakharova YuR (2020) Comparative analysis of freeliving and particle-associated bacterial communities of Lake Baikal during the ice-covered period. J Great Lakes Res 46:508-

https://doi.org/10.1016/j.jglr.2020.03.015

27. Cabello-Yeves PJ, Zemskaya TI, Rosselli R, Coutinho FH, Zakharenko AS, Blinov VV, Rodriguez-Valera F (2018) Genomes of novel microbial lineages assembled from the sub-ice waters of Lake Baikal. Appl Environ Microbiol 84:e02132-17. https://doi.org/10.1128/AEM.02132-17. e02132-17

28. Butler TM, Wilhelm A-C, Dwyer AC, Webb PN, Baldwin AL, Techtmann SM (2019) Microbial community dynamics during lake ice freezing. Sci Rep 9:6231. https://doi.org/10.1038/s41598-019-42609-9

29. Tran P, Ramachandran A, Khawasik O, Beisner BE, Rautio M, Huot Y, Walsh DA, (2018) Microbial life under ice: Metagenome diversity and in situ activity of Verrucomicrobia in seasonally ice-covered lakes. Environ Microbiol 20:2568-2584. https://doi.org/10.1111/1462-2920.14283

30. Somers DJ,Strock KE, Saros JE(2019) Environmental controls on microbial diversity in arctic lakes of West Greenland.Microb Ecol 80:6-72. https://doi.org 1007/s00248-019-01474-9

31. Vigneron A, Lovejoy C, Cruaud P, Kalenitchenko D, Culley A, Vincent WF (2019) Contrasting winter versus summer microbial communities and metabolic functions in a permafrost Thaw lake. Front Microbiol 10:1656. https://doi.org/10.3389/fmicb.2019.01656

32. Tomberg IV, Kopyrina LI, Bessudova AYu, Firsova AD, Bashenkhayeva MV, Zakharova YuR, Gorina EO (2017) Hydrochemistry and phytoplankton of the Lake Labynkyr and Lake Vorota (Sakha Republic). International conference "Lakes of Eurasia: problems and paths of their decision", Conference Proceedings, Petrozavodsk, pp 426-432 (In Russian)

33. Kopyrina L, Firsova A, Rodionova E, Zakharova Y, Bashenkhaeva M, Usoltseva M, Likhoshway Y (2020) The insight into diatom diversity, ecology, and biogeography of an extreme cold ultraoligotrophic Lake Labynkyr at the Pole of Cold in the northern hemisphere. Extremophiles 24:603https://doi.org/10.1007/s00792-020-01181-1

34. Usoltseva M, Kopyrina L, Titova L, Morozov A, Firsova A, Zakharova Y, Bashenkhaeva M, Maslennikova M, Likhoshway Y (2020) Finding of a putative Lake Baikal endemic, Lindavia minuta, in distant lakes near the Arctic pole in Yakutia (Russia). Diatom Res 35:141-153.

https://doi.org/10.1080/0269249X.2020.1747551

35. Zakharova YR, Bedoshvili YD, Petrova DP, Marchenkov AM, Volokitina NA, Bashenkhaeva MV, Kopyrina LI, Grachev MA, Likhoshway YV (2020) Morphological description and molecular phylogeny of two diatom clones from the genus Ulnaria (Kützing) Compère isolated from an ultraoligotrophic lake at the Pole of Cold in the Northern Hemisphere, Republic of Sakha (Yakutia), Russia. Cryptogam Algol 41:37-45. https://doi.org/10.5252/ cryptogamie-algologie2020v41a6

36. Kuzmin GV (1975) Techniques for Studying Biogeocenoses of Inland Water Bodies. Nauka, Moscow (In Russian)

37. Makarova IV, Pichkily LO (1970) To some problems on techniques of phytoplankton biomass estimation. Botanic J 55:1488-1494 (In Russian)

38. Wetzel RG, Likens GE, 2000. Composition and biomass of phytoplankton. In: Limnological analyses. Springer Verlag, New York. pp $147-174$.

39. Lane DJ, Pace B, Olsen GJ, Stahl DA, Sogin ML, Pace NR (1985) Rapid determination of 16S ribosomal RNA sequences for phylogenetic analyses. P Natl Acad Sci USA 82:6955-6959

40. Denisova LY, Bel'kova NL, Tulokhonov II, Zaichikov EF (1999) Bacterial diversity at various depths in the southern part of Lake Baikal as revealed by 16S rDNA sequencing. Microbiol 68:475-483.

41. Hall TA (1999) BioEdit: a user-friendly biological sequence alignment editor and analysis program for Windows 95/98/NT. In Nucleic Acids Symposium Series 41:95-98.

42. Tamura K, Stecher G, Peterson D, Filipski A, Kumar S (2013) MEGA6: Molecular Evolutionary Genetics Analysis, version 6.0. Mol Biol Evol 30:27252729

43. Rusch DB, Halpern AL, Sutton G, Heidelberg KB, Williamson S, et al. (2007) The Sorcerer II Global Ocean Sampling expedition: Northwest Atlantic through eastern tropical Pacific. PLoS Biol 5:e77. https://doi.org/10.1371/journal.pbio.0050077

44. Baker GC, Smith JJ, Cowan DA (2003) Review and re-analysis of domain-specific 16S primers. J Microbiol Methods 55:541-555. https://doi.org/10.1016/j.mimet.2003.08.009

45. Edgar RC (2010) Search and clustering orders of magnitude faster than BLAST. Bioinformatics 26:2460-2461.

46. Oksanen J, Blanchet FG, Friendly M et al (2016) vegan: community ecology package. version 2.4-1. https://CRAN.R-project.org/package=vegan

47. McMurdie PJ, Holmes S (2013) phyloseq: an R package for reproducible interactive analysis and graphics of microbiome census data. PLoS ONE 8:e61217. https://doi.org/10.1371/journal.pone.0061217

48. Suzuki R, Terada Y, Shimodaira H (2019) pvclust: hierarchical clustering with p-values via multiscale bootstrap resampling. R package version 2.20. https://CRAN.R-project.org/package=pvclust

49. Love MI, Huber W, Anders S (2014) Moderated estimation of fold change and dispersion for RNA-seq data with DESeq2. Genome Biol 15:550. https://doi.org/10.1186/s13059-014-0550-8

50. Potapova NA, Nazyrova RI, Zabelina NM, Issaeva-Petrova LS, Korotkov VN, Otchagov DM (2006) Reference book of protected areas of the Russian Federation P II. ARRINP, Moscow

51. Bessudova AU, Tomberg IV, Firsova AD, Kopyrina LI, Likhoshway YV (2019) Silica-scaled chrysophytes in lakes Labynkyr and Vorota, of the Sakha (Yakutia) Republic, Russia. Nova Hedwigua 148:35-48. https://doi.org/10.1127/nova-suppl/2019/049

Page $11 / 15$ 
52. Twiss MR, McKay RML, Bourbonniere RA, Bullerjahn GS, Carrick HJ, Smith REH, Winter JG, D'souza NA, Furey PC , Lashaway AR,. Saxton MA, Wilhelm SW (2012) Diatoms abound in ice-covered Lake Erie: an investigation of offshore winter limnology in Lake Erie over the period 2007 to 2010. J Great Lakes Res 38:18-30. https://doi.org/10.1016/j.jglr.2011.12.008

53. D'souza NA, Kawarasaki Y, Ganyz JD et al. (2013) Diatom assemblages promote ice formation in large lakes. ISME J 7:1632-1640

54. Cruaud P, Vigneron A, Fradette M-S, Dorea CC, Culley Al, Rodriguez MJ, Charette SJ (2020) Annual bacterial community cycle in a seasonally icecovered river reflects environmental and climatic conditions. Limnol Oceanogr 65:S21-S37. https://doi.org/10.1002/Ino.1113

55. Møller AK, Søborg DA, Abu Al-Soud W, Sørensen SJ, Kroer N (2013) Bacterial community structure in High-Arctic snow and freshwater as revealed by pyrosequencing of 16S rRNA genes and cultivation. Polar Res 32:17390, https://doi.org/10.3402/polar.v32i0.17390

56. Papale M, Rizzo C, Villescusa JA, Rochera C, Camacho A, Michaud L, Lo Giudice A (2017) Prokaryotic assemblages in the maritime Antarctic Lake Limnopolar (Byers Peninsula, South Shetland Islands). Extremophiles 21:947-961. https://doi.org/10.1007/s00792-017-0955-x

57. McKay RM, Prašil O, Pechar L, Lawrenz E, Rozmarynowycz MJ, Bullerjahn GS (2015) Freshwater ice as habitat: partitioning of phytoplankton and bacteria between ice and water in central European reservoirs. Environ Microbiol Rep 7:887-898.

58. Newton RJ, Jones SE, Eiler A, McMahon KD, Bertilsson S (2011) A guide to the natural history of freshwater lake bacteria. Microbiol Mol Biol Rev 75:14-49. https://doi.org/10.1128/MMBR.00028-10

59. Crump BC, Kling G W, Bahr M, Hobbie JE (2003) Bacterioplankton community shifts in an Arctic lake correlate with seasonal changes in organic matter source. Appl Environ Microbiol 69:2253-2268. https://doi.org/10.1128/AEM.69.4.2253-2268.2003

60. Logares R, Lindstro“m ES, Langenheder S, Logue JB, Paterson H, Laybourn-Parry J, Rengefors K, Tranvik L, Bertilsson S (2013) Ecology of microbial communities exposed to drastic long-term environmental change. ISME J 7:937-948. https://doi.org/10.1038/ismej.2012.168

61. Mikhailov IS, Zakharova YR, Bukin YS, Galachyants YP, Petrova DP, Sakirko MV, Likhoshway YV (2019) Co-occurrence networks among bacteria and microbial eukaryotes of Lake Baikal during a spring phytoplankton bloom. Microb Ecol 77:96-109. https://doi.org/10.1007/s00248-018-1212-2

62. Llorens-Marès T, Auguet JC, Casamayor EO (2012) Winter to spring changes in the slush bacterial community composition of a high-mountain lake (Lake Redon, Pyrenees). Environ Microb Rep 4:50- https://doi.org/10.1111/j.1758-2229.2011.00278.x

63. Eiler A, Bertilsson S (2005) Composition of freshwater bacterial communities associated with cyanobacterial blooms in four Swedish lakes. Environ Microbiol 6:1228-1243. https://doi.org/1111/j.1462-2920.2004.00657.x

64. Pearce DA, van der Gast CJ, Lawley B, Ellis-Evans JC (2003) Bacterioplankton community diversity in a maritime Antarctic lake, determined by culture-dependent and culture-independent techniques. FEMS Microb Ecol 45:59-70

65. Miteva V, Sheridan PP, Brenchley JE (2004) Phylogenetic and physiological diversity of microorganisms isolated from a deep Greenland glacier ice core. Appl Environ Microbiol 70:202-213. https://doi.org/10.1128/AEM.70.1.202-213.2004

66. Michaud L, Caruso C, Mangano S, Interdonato F, Bruni V, Lo Giudice A (2012) Predominance of Flavobacterium, Pseudomonas, and Polaromonas within the prokaryotic community of freshwater shallow lakes in the northern Victoria Land, East Antarctica. FEMS Microbiol Ecol 82:391-404. https://doi.org/10.1111/j.1574-6941.2012.01394.x

67. Margesin R, Miteva V (2011) Diversity and ecology of psychrophilic microorganisms. Res Microbiol 162:346-361. https://doi.org/10.1016/j.resmic.2010.12.004

68. Abraham WP, Raghunandanan S, Gopinath V, Suryaletha K, Thomas S (2020) Deciphering the cold adaptive mechanisms in Pseudomonas psychrophila MTCC12324 Isolated from the Arctic at 79² N. Curr Microbiol 77:2345-2355. https://doi.org/10.1007/s00284-020-02006-2

69. Bull AT (2011) Actinobacteria of the ex In: Horikoshi K, Antranikian G, Bull AT, Robb FT, Stetter KO (eds) Extremophiles handbook, Springer, Japan. pp. 1203-1240.

70. Hansen A A, Herbert RA, Mikkelsen K, Jensen LL, Kristoffersen T, Tiedje JM, Lomstein BA, Finster KW (2007), Viability, diversity and composition of the bacterial community in a high Arctic permafrost soil from Spitsbergen, Northern Norway. Environ Microbiol 9:2870-2884.

https://doi.org/1111/j.1462-2920.2007.01403.x

71. Miteva V, Teacher C, Sowers T, Brenchley J (2009) Comparison of the microbial diversity at different depths of the GISP2 Greenland ice core in relationship to deposition climates. Environ Microbiol 11:640-656

72. Vishnivetskaya TA, Petrova MA, Urbance J, Ponder M, Moyer CL, Gilichinsky DA, Tiedje JM (2006) Bacterial community in ancient Siberian permafrost as characterized by culture and culture-independent methods. Astrobiology 6:400-414

73. Steven B, Pollard WH, Greer CW, Whyte LG (2008) Microbial diversity and activity through a permafrost/ ground ice core profile from the Canadian high Arctic. Environ Microbiol 10:3388-3403

74. Bottos EM, Vincent WF, Greer CW, Whyte LG (2008) Prokaryotic diversity of arctic ice shelf microbial mats. Environ Microbiol 10:950-966

75. Durán N, Justo GZ, Ferreira CV, Melo PS, Cordi L, Martins D (2007) Violacein: properties and biological activities. Biotechnol Appl Biochem 48:127https://doi.org/10.1042/BA20070115

76. Baricz A, Teban A, Chiriac CM, Szekeres E, Farkas A, Nica M, Dascălu A, Oprișan C, Lavin P, Coman C (2018) Investigating the potential use of an Antarctic variant of Janthinobacterium lividum for tackling antimicrobial resistance in a One Health approach Sci Rep 8:15272.

https://doi.org/10.1038/s41598-018-33691-6

Page $12 / 15$ 
77. Van Trappen S, Mergaert J, Van Eygen S, Dawyndt P, Cnockaert MC, Swings J (2002) Diversity of 746 heterotrophic bacteria isolated from microbial mats from ten Antarctic lakes. Syst Appl Microbiol 25:603-610.

78. Peeters K, Hodgson DA, Convey P, Willems A (2011) Culturable diversity of heterotrophic bacteria in Forlidas Pond (Pensacola Mountains) and Lundstrom Lake (Shackleton Range), Antarctica. Microbiol Ecol 62:399-413

79. Miteva VI, Brenchley JE (2005) Detection and isolation of ultrasmall microorganisms from a 120,000-year-old Greenland glacier ice core. Appl Environ Microbiol 71:7806-7818.

80. Amato P, Hennebelle R, Magan O, Sancelm M, Delort A-M, Barbant C, Boutron C, Ferrari C (2007) Bacterial characterization of the snow cover at Spitzberg, Svalbard. FEMS Microbiol Ecol 59:255-264. https://doi.org/10.1111/j.1574-6941.2006.00198.x

81. Christner BC, Mosley-Thompson E, Thompson LG \& Reeve JN (2001) Isolation of bacteria and 16S rDNAs from lake Vostok accretion ice. Environ Microbiol 3: 570-577.

\section{Figures}

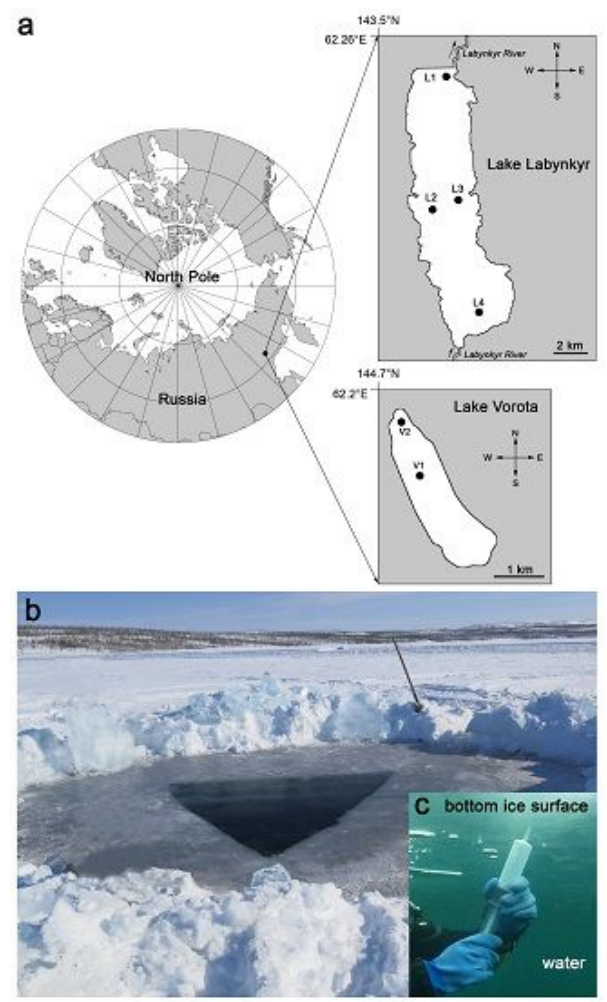

\section{Figure 1}

Sampling sites in lakes. Note: The designations employed and the presentation of the material on this map do not imply the expression of any opinion whatsoever on the part of Research Square concerning the legal status of any country, territory, city or area or of its authorities, or concerning the delimitation of its frontiers or boundaries. This map has been provided by the authors.

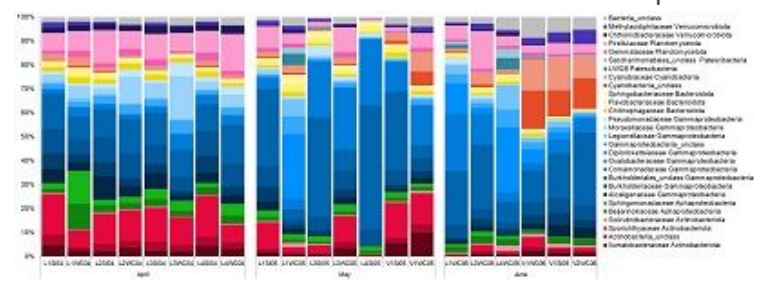

\section{Figure 2}

Taxonomic composition of bacterial communities based on data from a sequencing of the V3-V4 regions of the 16S rRNA gene and bacterial classification from the SILVA v.138 database. 


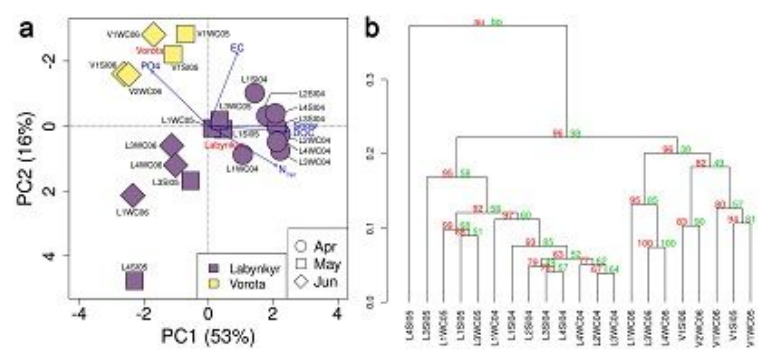

Figure 3

Unconstrained ordination and clustering of top 58 OTUs. a PCA ordination of log2( $x+1)$-transformed OTU counts. Exploratory variables with Holmadjusted $p$-values $\leq 0.01$ are indicated by the blue vectors. Red labels show positions of centroids for "lake" factor variable; b UPGMA-dendrogram computed on a matrix of Bray-Curtis dissimilarity distances. Red and green numbers indicate the "approximately unbiased" p-values and "bootstrap probability" values, respectively.

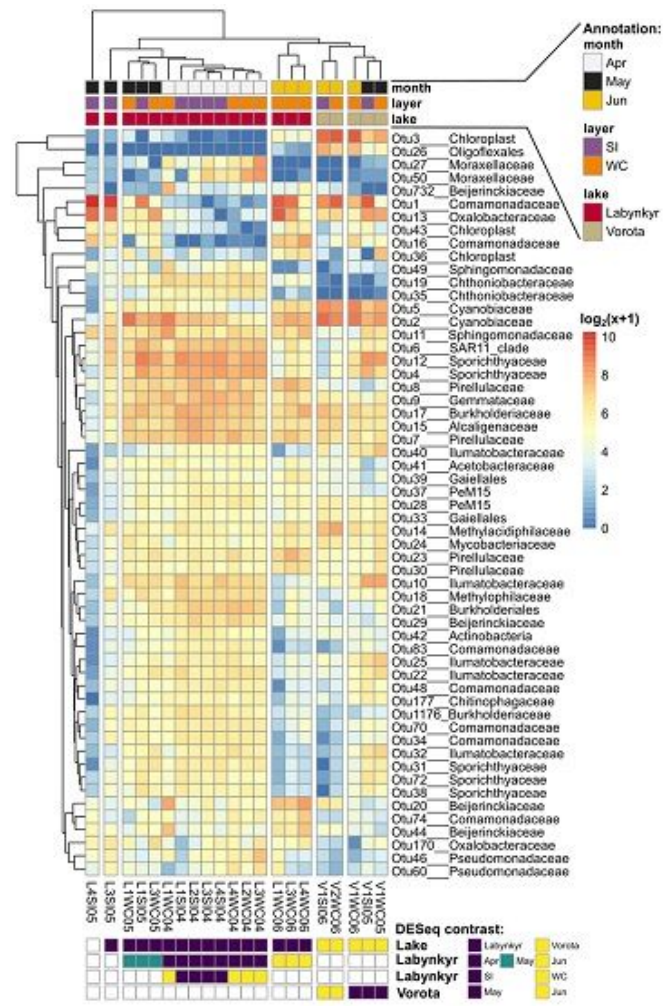

Figure 4

Hierarchical clustering of log2(x+1)-transformed OTU counts. Rows - OTUs, columns - samples. Clustering was performed on a matrix of Bray-Curtis dissimilarity distances. Clustering dendrogram of columns is a minimized version of UPGMA-tree in Fig $3 \mathrm{~b}$. The color-coded annotation of samples is drawn in the upper part of the heatmap. The grouping of samples used for differential abundance analysis by DESeq2 is indicated in the bottom part of the heatmap.

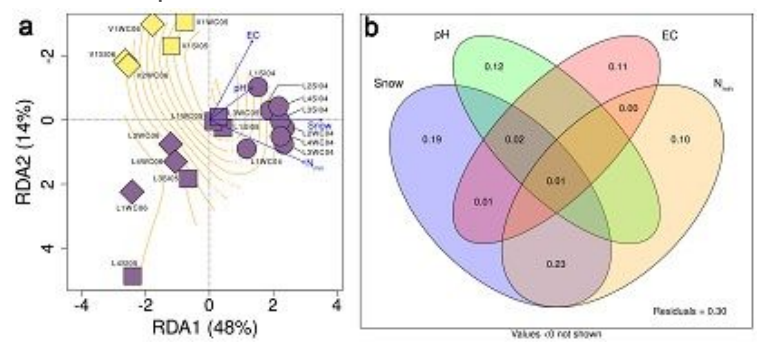

Figure 5

Constrained ordination of top 58 OTUs. a Transformation-based RDA with exploratory variables chosen by "forward selection" approach. Exploratory variables included in the final model are indicated by the blue vectors. Gradient of $\mathrm{pH}$ is drawn by orange lines; $\mathrm{b}$ Venn diagram describing the variance partitioning. 


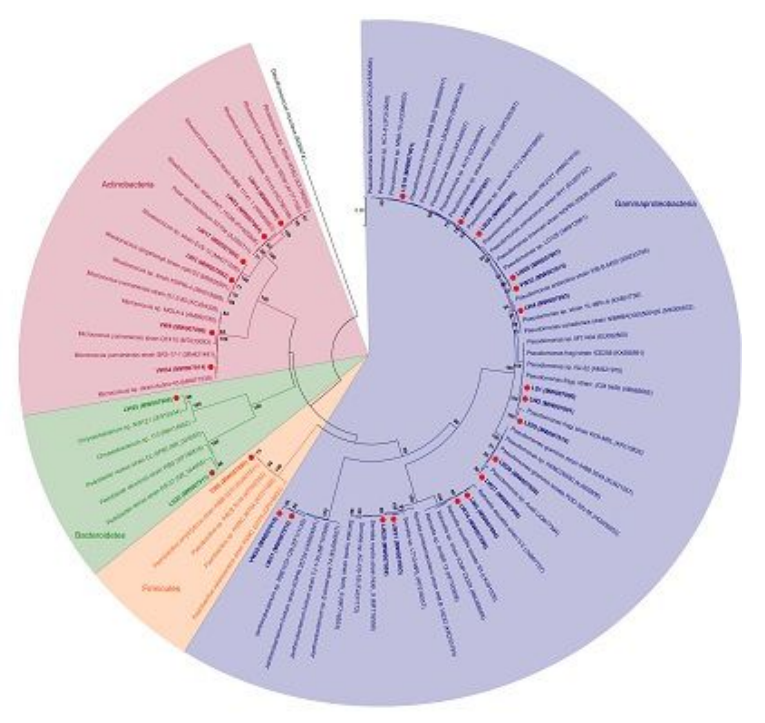

Figure 6

Phylogenetic tree of 16S rRNA nucleotide sequences of bacteria from under ice communities. Digits indicate the reliability of ramification found by means of the "bootstrap" analysis of 1000 alternative trees; isolated strains are marked with red circles.

\section{Supplementary Files}

This is a list of supplementary files associated with this preprint. Click to download.

- Certificate2021042652126.pdf

- ElectronicSupplementaryMaterial.docx 